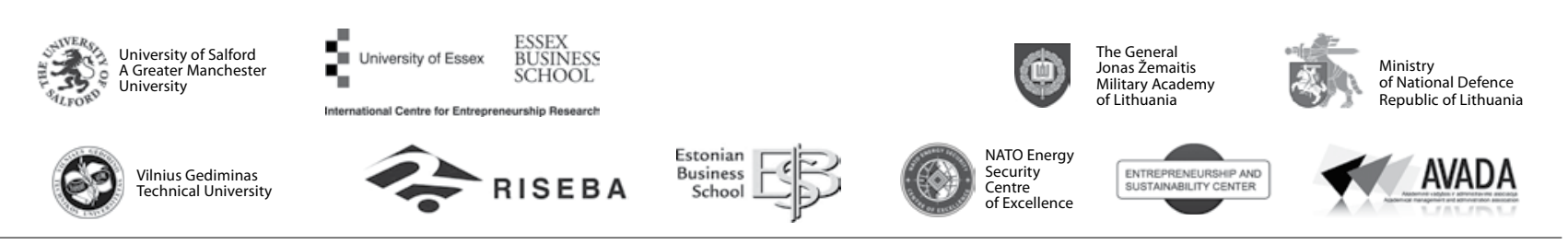

\author{
JOURNAL OF SECURITY AND SUSTAINABILITY ISSUES \\ ISSN 2029-7017 print/ISSN 2029-7025 online \\ 2017 March Volume 6 Number 3 \\ http://dx.doi.org/10.9770/jssi.2017.6.3(6)
}

\title{
NATIONAL SECURITY STRENGTHENING THROUGH THE OPERATIONAL ACTIVITIES LAW
}

\author{
Igors Trofimovs ${ }^{1,3}$, Jānis Ivančiks ${ }^{2,3}$ \\ ${ }^{1}$ The State Police College of Latvia, Ezermalas Str. 8, Riga, LV-1014, Latvia \\ ${ }^{2}$ Turiba University, Graudu Str. 68, Riga, LV-1058, Latvia \\ ${ }^{3}$ Daugavpils University, Parades Str. 1, Daugavpils, LV-5401, Latvia \\ E-mails:1'dakpt@inbox.lv; 2,3 janis.ivanciks@inbox.lv
}

Received 15 May 2016; accepted 26 November 2016

\begin{abstract}
The basis of this paper is the study of legislative acts of such counties as Latvia, Lithuania, Estonia, Poland, Ukrainie and Russia, related to national security, public order and interests of state prosperity in order to prevent disorders or crimes, to protect health and morality, to safeguard rights and freedoms. The objective of the paper is to assess whether the national legislation meets in this field contemporary requirements, and what are differences in comparison with the legislation of other countries. Our results show that the laws of above mentioned countries are supplemented in due time as much as possible taking into account needs and financial resources of corresponding state. The laws have also similar objectives and tasks. There are some distinctions in application of legal provisions, which, after discussion, would be usefully to introduce into normative regulations of the Republic of Latvia. The norms of law must be clearly defined; the commensurate restrictions must be appropriate for achievement of particular objective, as well as socially necessary. Moreover, the authors of the paper offer concrete proposals taking into account human rights, contemporary situation on the international scene, as well as potential of respective state institution.
\end{abstract}

Keywords: security, government, human rights, law, crime.

Reference to this paper should be made as follows: Trofimovs, I; Ivančiks, J. 2017. National security strengthening through the operational activities law, Journal of Security and Sustainability Issues 6(3): 391-400. http://dx.doi.org/10.9770/jssi.2017.6.3(6)

JEL Classifications: K42, O10, P00

\section{Introduction}

The priority of the state is safeguarding of interests of national security, public order and state prosperity, prevention of disorders or crimes, protection of health and morality, as well as protection of rights and freedoms. For the implementation of this priority, each country has developed state institutions, which puts into effect state administration, resp., executive and local institutions, that, in its turn, must ensure execution of certain directions.

State authorities which function by law is ensuring of lawfullness and legal procedures, protection of rights and legal interests of persons and the State, elimination of infringement of rights, application of state coercive methods or public affecting means to infringers of rights are called law enforcement institutions. The system of law enforcement institutions consists of all existing institutions of the state, main function of which is protection of rights. Each of these institutions operates within its competence, and, cooperating between each other, forms system of these institutions which task is the protection of rights (Zahars, Stivrenieks 2016). The protection of rights express itself as follows: administration of justice, prosecutor's activities, investigation of offences, protection of public order, protection of interests and rights of individuals, legal advice work, social activities focusing on strengthening of legal order. 
As one of the elements of the system of law enforcement institutions are authorities, core competence of which is prevention, detection and investigation of criminal offences. In all countries of the world, including Latvia, an significant part of crimes are committed covert, in order that the police do not find out about crimes at all or find out about those as late as possible. In recent years, criminals, in particular organized criminal groups counteract secretly, actively and purposefully to the police activities to detect and investigate their crimes (Tumalavičius et al. 2016). Therefore, to avert and detect crime and to detain offenders, all countries have formed special police units: in Germany - Kriminalpolizei, in France - Sjuerte, in Great Britain - Scotlandyard, in the United States of Amerika - Federal Bureau of Investigation, in Russia - Ugolovnyi rozysk, in Poland - Policja kryminalna, in the Ukraine - Kriminalna miliciya, in Lithuania - Kriminaline policija, in Latvia - Kriminalpolicija.

The environment, in which special police units operate, is rapidly changing around the world (Štitilis et al. 2016; Gasparėniené et al. 2016; Teivāns-Treinovskis, Amosova 2016; Tvaronavičienė et al. 2016; Allabouche et al. 2016; Pauceanu 2016). These changes are related not only to criminal environment, but also to abilities of special police units to combat it. There are three basic components in the structure of special police units, without which such authority can not exist - legal basis, personnel, and material resources. In response to challenges of criminal environment, the countries must provide contemporary legislation to materially wellequipped personnel.

Each country has its own historical evolution, incl. own history of laws and regulations governing the operation of special police units (Lavrinenko et al. 2016). The authors of the paper analyze the corresponding laws and regulations of Latvia, Lithuania, Estonia, Ukraine, Poland and Russia in this field. The desire to study exactly these countries results from the fact that the development of national legislation of above mentioned countries was influenced by similar history, scientific sources, mentality of population.

Taking into account the above mentioned, the authors are searching the answer to the questions - does the legislation, which regulates actions of special police units, meet the modern requirements, and are amendments necessary?

\section{Problems of improvement of operational activities law}

Ongoing changes in all spheres of life in Latvia and in other countries reflect also in criminal environment. New kinds of crimes have appeared, which are characterized by a high degree of organization and criminal professionalism (Teivans-Treinovskis, Lavrinenko 2016). In such situation, new approaches are required in combat against criminality; and main attention is paid to operational activities.

The legal practice demonstrates with certainty that out-of-date legislation in the sphere of operational activities develops into incompetence, in inability of operational personnel, inspectors, prosecutors and judges to use purposefully the results of operational activities, that, after all, reduces significantly the effectiveness of crime combatting measures.

In order of successful implementation of the tasks of combating criminality, the State have to equipp operational personnel with legislation that reflects changes in the country and in the world, changes in the legislation, as well as positive trends in the application of legislation in practice.

Operational activities are a significant quantum of legal actions which helps to ensure the security of persons, society and the State, that is important both for individuals and for the state system on the whole, therefore, the legal basis of operational activities will be studied in this paper.

The authors believe that objectives and tasks of the operational activities must be clearly defined in the law, because the measures of operational activites are prohibited for other tasks and objectives (Operatīvas darbības likums, 1993). However, every year the International Court of Human Rights starts proceedings related to measures of operational activities performed by the police and other law enforcement institutions. The reason 
of cases are a variety of violations of human rights when obtaining information during measures of operative activities of the police.

The Operational Activities Law of the Republic of Latvia (hereinafter - OAL) was amended ten times (Grozījumi Operatīiās darbības likumā, 2016). The objectives of the amendments were diverse, but, in essence, they were focused on elimination of incompleteness in laws and regulations; on impossibility of involuntariness and uncontrolled actions of bodies of operational activities; on impossibility of malicious use of official powers; on fully respect of fundamental rights of individuals; on the possibility that the person may get information in Latvia, whether the information is gathered about him/her, of what nature the information is; on guaranteeing that this information is not accumulated unsuitable in order to minimize the interference risk into private life.

Recent amendments of OAL of 10.03.2016 are related to improvement of protection of fundamental rights of persons, prescribing clearly in amendments, in which cases the measures of operational activities are acceptable. Amendments prescribe also more detailed procedures how to obtain an approval of corresponding independent body for measures of operational activities performed in accordance with the special method; the amendments set up that operational activities shall not be performed, if its objectives and tasks may be achieved by means and methods of criminal process.

Recent amendments prescribe also more detailed procedures according to which an approval shall be received for measures of operational activities performed in accordance with the special method, as well as the procedure is prescribed according to which the approval of a judge shall be obtained in cases when measures of operational activities, performed in accordance with the special method, have been already initiated in urgent cases. The amendments state that for tracing of a person more than 30 days, the permit of a judge will be required.

A new operational measure has been introduced - investigatory inspection of business transactions in customer's account of a credit institution or financial institution. Moreover, the procedure has been prescribed according to which the body, performing operational activities, informes the person, against whom the above mentioned measure had been performed, about time and measure of operational activities which was performed in accordance with the special method. In addition, the Law has been supplemented by an action of specially authorized prosecutor in the case of submission of a complaint on possible action of an official of bodies performing operational activity that violates legitimate rights and freedoms of persons.

During studying the amendments, the authors came to the opinion that the alterations made in Section 2, Paragraph One Part 4 of the OAL, prescribes only searching of the property gained in a unlawful way, hence reducing possibilities of body performing operational activities to provide the compensation of damage.

The amendments limit also the possibility of application of Section 2, Paragraph One, Part 7 of the OAL up to protection of state secrets, despite the fact that also investigation secret, secrets of the EU and NATO exist, which are not a part of the category of state secrets.

It is not understandable the motivation of addition of Section 2 of the OAL with the Paragraph/Part Seven. The prohibition to obtain information purposefully using measures of operational activities on time when professional assistance of sworn advocates, doctors, psychologists and clergypersons of registered religious organizations is provided, except occasions when an investigatory process is carried out against mentioned persons according to the procedure stated in this Law, means that if the object is not exposed to investigatory process, it is not allowed to perform investigatory inquiring during the work of a doctor or psychologist, the situation may arise when it will be not possible to perform inquiring of a doctor of a reception department about possible origin of body injury to the patient.

Amendments of Section 7, Paragraph Six of the OAL prescribe to exclude the provisions of the previous version that an approval of a judge is not necessary for performance of measures of operational activities in accordance with special method against detainees, suspects, accused persons, persons on trial and convicts in the 
investigatory premises of bodies of operational activities or penitentiary institutions. Obtaining of the approval of a judge according to common conditions on performance of measures in accordance with special method within 48 hours, would be, in practice, very difficult, and even obtaining of this approval for some hours, while relevant documents are prepared - will not be longer urgent (Ivančiks 2013). There is contradiction of the amendments to the provisions stated in Section 18, Paragraph Two of the OAL, which stipulates that the process of operational activity may begin before criminal procedure starts, it may go on during the criminal proceedure, and also continue after its completion.

\section{Foreign normative regulation in the field of operational activities}

The environment, in which law enforcement institutions work, is rapidly changing around the world. These changes are related not only to the criminal environment, but also to the ability of law enforcement institutions to combat it. Each country has own historical evolution, incl. own history have also laws and regulations governing the operational activities. The authors analyze in the paper the normative documentation - laws and regulations of Latvia, Lithuania, Estonia, Ukraine, Russia and Poland actual for this area. The desire to study exactly these countries is rooted in the fact that the development of national legislation of above mentioned states was influenced by similar history, scientific sources, mentality of population.

Operational activities are a significant scope of legal actions which helps to ensure security of individuals, the society and the State, that is important both for individuals and for the state polytical system in total. For this reason, the legal regulation of operational activities has been searched. In order to do it, the definition of operational activity was searche which is included in the laws regulating the operational activities: in Latvia - Operatīvās darbības likums (The Operational Activities Law), in Lithuania - Lietuvos Respublikos kriminalinès žvalgybos įstatymas, 10-02-2012, No. XI-2234 (The Law on Criminal Intelligence of the Republic of Lithuania). (Here and hereinafter - translation of the authors), in Estonia - Jälitustegevuse seadus, Vastu võetud 22-02-1994, RT I 1994, 16, 290 (The Law on Video Surveillance), in Poland - Ustawa o czynnościach operacyjno-rozpoznawczych 04-02-2016 (The Law on Operational Intelligence Activities), in the Ukraine Zakon Ukrainy pro operativno-pozshukovu diyatelnost, 03-27-1992 (The Law of Ukraine on Operational Searching Activities), and in Russia - Federalnyi Zakon "Ob operativno-rozysknoj dejatelnosti", 12-08-1995, No. 144-3 (The Federal Law on Operational Searching Activities).

During studying these Laws, it became evident that the titles of the Laws that regulate the law enforcement institutios (the subject of operational activities researched in this paper - the Police) in Latvia, Poland, Ukraine and Russia are similar, while in Lithuania and Estonia - different. There are differences also in the time periods of adoption of the Laws: in Latvia - in 1993, in Estonia - in 1994, in Poland - in 2008, in Ukraine - in 1992, in Russia - in 1995, and in Lithuania - in 2012.

Further, the authors will study, how the Laws define the activities which are to be performed.

The operational activities, stated in the Operational Activities Law of the Republic of Latvia, are the overt and covert legal activities, of specially authorised - pursuant to the procedures prescribed in this Law, and by law officials of State authorities, the objectives of which are the protection of the life and health, rights and freedoms, honour, dignity and property of persons and the safeguarding of the Constitution, the political system, national independence and territorial integrity, the capabilities of the State regarding defence, the economy, science and technology, and State official secrets, against external and internal threats (Operatīvas darbības likums, 1993).

In the Law of Lithuania, corresponding activity is the criminal intelligence - actions of bodies of criminal intelligence stated by the Law and focused on collecting, recording, evaluation and use of information, being in possession, on objects of criminal intelligence (Lietuvos Respublikos kriminalinès žvalgybos įstatymas, 2012). According to the corresponding Law of Estonia, it is the operational searching activity - overt and covert actions of operational searching services, prescribed according to the Law (Jälitustegevuse seadus, 1994). 
Ooperational intelligence activities, according to the Law of Poland, are actions performed overt and covert, and only with objective to identify, prevent and detect offences; to find people who are in hiding of investigation and the court; to search for missing persons, to find lost property, if there is a reasonable suspicion that it is criminally acquired property, or it is related to a criminal offense (Ustawa o czynnościach operacyjnorozpoznawczych, 2008).

The corresponding Law of Ukraine defines operational searching activities as follows: it is scope of overt and covert searching, measures of ntelligence and counter-intelligence activities performed using operational and operational technical means (Zakon Ukrainy pro operativno-pozshukovu diyatelnost, 1992).

In accordance with the Law of Russia, operational searching activities are actions executed overt and covert by operational structural units of state institutions that are authorized by the Federal Law, performing operational searching measures with purpose to protect the life, health, rights, freedom, property of persons, to ensure public and national security against criminal threats (Federalnyi Zakon, 1995).

The overall conclusion is that the definition of actions, which are to be performed, are different in each country, however all countries have some common concepts:

- activities are performed by certain bodies (of operational activities), and such bodies are officials of state institutions or bodies of criminal intelligence, specially authorized by law, or operational structural units of a state institution, which is one and the same;

- activities are overt and covert.

Unlike the definition of Lithua, Estonia and Ukraine, the definitions of operational activities in the Laws of Latvia, Poland and Russia still include also objectives of operational activities, which are similar.

In other words, the objective of operational activity is to ensure protection and prevent risks of damage and threats both for security of single individual (person) and the whole society, as well as to protect the rights of a person in the society. Pursuant to this objective, the Operational Activities Act defines also the tasks of operational activities.

Section 2 of the "Operational Activities Law" of the Republic of Latvia states the tasks of operational activities as follows (Operational Activities Law, 1993):

1) the protecting of persons against criminal threats;

2) preventing, deterring and detecting of criminal offences, and the determining of persons committing criminal offences and the sources of evidence;

3) searching for persons who, in accordance with procedures laid down in law, are suspected of, have been accused of or have been convicted of committing a criminal offence;

4) ensuring compensation for damages resulting from a criminal offence;

5) searching for such persons who have left their permanent or temporary place of residence suddenly and without obvious reason, deviate from their usual lifestyle and it is not possible to reach them, as well as searching for minors and such persons who are to be taken care of because of their age, physical or mental condition or illness, but who have left home, medical treatment institutions or other places of residence (missing persons);

6) obtaining, accumulating, analysing and utilising, in accordance with procedures laid down in law, of political, social, military, economic, scientific and technical, criminal, and other information related to the criminal sphere and its infrastructure, and threats against State security, defence and economic sov ereignty;

7) the protecting of official secrets and other interests important to the State, and, in cases laid down in law, the providing of special protection to persons;

8) gathering of information about specific persons, if decisions must be taken on their suitability for work in important State offices and for authorities, or regarding persons who have access to official secrets or other secrets protected by law. 
The tasks of the criminal intelligence (The Law on Criminal Intelligence of the Republic of Lithuania, 2012), stated in Section 4 of the Law of Lithuania, are identical with the tasks defined in the OAL of Latvia, except that the protection of state secrets and protection of other interests wich are important for the State is not stipulated, as well as in the cases prescribed by the Law - ensuring of the special protection of persons, and acquisition of information about certain persons, if the issue of their compliance with appointment for important public service positions and state institutions have to be desided; or information about persons who have access to state secrets or other secrets protected by law, which are stipulated in the OAL.

Sectiom 3 of the Law of Estonia (The Law on Video Surveillance, 1994) defines the task of operational searching activities as acquisition of data, and the performance of activities, allowed by law, what is necessary in order to stop prepared or to be commited crimes, to detect committed crimes, to find offenders, to compensate the damages coused by crimes, and to search for other facts important in investigation, to detain manhunted persons, as well as to find missing persons.

In section 1 of the Law of Ukraine (The Law of Ukraine on Operational Searching Activities, 1992), operational searching activities are defined as searching and fixing of actual data on illegal activities of single persons and groups with the aim to stop infringements of law in favour of criminal proceedings, as well as acquisition of information in favour of citizens, society and the State, responsibility for which is prescribed in the Criminal Code of the Ukraine, on intelligence and sabotage activities of special services of foreign countries and organizations.

The tasks of operational searching activities (The Federal Law on Operational Searching Activities, 1995) stated in section 2 of the corresponding Law of Russia, are identical with the tasks prescribed in the OAL of Latvia.

So, the tasks of operational activities are set out in the Laws a little different in each country, however, in general it may be defined that they are the same in its terms. They are: acquisition, accumulation, analysis and use of information, according to the Law, on criminal offenses and threats related to the life, freedom, health of person, to fundamental rights and the state polytical system.

The authors believe that tasks and objectives of operational activities must be clearly defined in the Law, because the measures of operational activities are prohibited for implementation of other tasks and objectives (The Operational Activities Law, 1993).

Successful run of operational activities is depending on many factors, and one of these is compliance of measures of operational activity and used technical means with contemporary requirements. Actions of representatives of criminal environment, in contrast to the police actions, are not limited neither by laws, not by financial means.

Therefore, it is necessary to clarify whether the measures of operational activities comply with contemporary requirements.

During the research, the authors came to conclusion that measures of acquisition of information of the studied countries are, in point of fact, the same, despite of their imaginary differences.

Various methods and tactical techniques have been applied during the implementation of measures of acquisition of information, that are state secrets (The Operational Activities Law, 1993) not only in the Republic of Latvia, but also in all other countries.

The use of modern technologies in this field is one of the basis for development and adoption of amendments of the Operational Activities Law, as well as a basis for development and implementation of new tactical and methodological techniques. This allows the possibly less intervention in the area of human rights, enable to acquire true, complete and accurate information in optimal time. 
In relation to the bodies of operational activities, this system is composed in Latvia of the Constitution Protection Bureau, the Security Police, the Military Intelligence and Security Service, the State Police, the Military Police, the Financial Police, the Customs Criminal Board, the Corruption Prevention and Combating Bureau, the State Border Guards, the Prison Administration, the Internal Security Bureau. These institutions have the right to be the subjects/bodies of operational activities according to special law.

Subjects/bodies of operational activities of other studied countries are prescribed by the national OAL of each country, and subjects may differ in number. However, in its terms, these subjects are similar to the corresponding bodies in Latvia - they are institutions ensuring national security, defense and public order.

When researching protection of rights and freedom of persons of the studied countries, it may be concluded: in Latvia, Poland, if a person considers that a body of operational activity has violated his/her legitimate rights and freedoms, this person is entitled to submit a complaint to public prosecutor, as well as a person may applay in a acourt. In Lithuani; Russia - to a head of a body of operational activities to a prosecutor and in a court; in Estonia - to a head of a body of operational activities, as well as in a court; in Ukraine - to a head of a body of operational activities and to a prosecutor.

When analyzing procedures according to which an approval shall be obtained for performance of measures of operational activities that injure the fundamental rights of persons, it may be concluded that in all studied countries, they may be performed according to the approval of different court levels, e.g. from a district/town court and up to Tallinn administrative court in Estonia, and up to the Supreme Court in Latvia.

Legislators of Latvia, Lithuania, Estonia and Poland prescribe to inform person, against whom measures of operational activities are performed, which violate the fundamental rights of persons, about performed operational activities.

\section{Proportionality of restrictions of human rights, when performing operational activities}

In Latvia, there are problems and disagreements on matters of guaranteeing of human rights, when restricting human rights of persons in public interests.

Compliance with the principles of proportionality means that possible public benefit from restriction must be realistic and greater than the restrictions imposed to person's rights, freedoms and interests. Proportionate restriction must be appropriate to the achievement of actual purpose, as well as must be socially necessary.

Restrictions prescribed by the State are juridical only if they meet the following preconditions:

1) restriction of fundamental rights is prescribed by law;

2) restriction has a legitimate aim (it should attempt to achieve one of these aims - ensuring of national security; territorial integrity or interests of public security; prevention of disorders or crimes; securing of health, morality, other human rights and freedoms);

3) restriction is proportionate to its legitimate aim.

Section 116 of the Constitution of the Republic of Latvia states that the person's rights may be restricted in certain cases indicated by law, in order to protect rights of other people, democratic state system, public safety, prosperity and morality.

When explaining the rights to privacy guaranteed by Section 96 of the Constitution of the Republic of Latvia, the Constitutional Court has indicated that these rights affect a variety of aspects. They protects physical and moral integrity, honor and dignity, name and identity, personal data of individuals. The right to privacy means that an individual is entitled to his/her own private space, to live in own way, to develop and improve own personality according to own nature and desires, suffering minimally as much as possible from intervention of the State or other persons. These rights include also the right of individuals to be different, to preserve and de- 
velop features and capabilities that distinguish him/ her from other persons and individualizes him/her (Latvian Constitutional Court Verdict, 2010).

An increasing number of complaints of recent years testifies that the Police have a number of serious problems in observing of human rights and fundamental freedoms, and the internal investigation mechanism has not olways functioned effectively and transparently (The European Court of Human Rights. Baltiňš vs. Latvia, the case No.25282/07; Vetter vs. France, the case No.59842/00; Heglas vs. Czech Republic, the case No.5935 / 02; the Judgement of the Constitutional Court of the Republic of Latvia, the case No. 2010-55-0106; the Judgment of the Supreme Court of the Republic of Latvia SKA - 996/2013, and others.).

The trust in prohibition of violations of human rights has been reduced each time when the guilty officials are not called to justice for their actions.

If the information about such violations has been appeared, and a rapid and effective response does not follow, then those, who are inclined to behave in this manner, start thinking that they may act bravely and go unpunished. In such a case, any attempts to try to introduce principles of human rights through a careful selection of staff and professional training are sabotaged. Without taking effective measures of elimination of violations of human rights, it contributes inevitably to destroy values which form the base of democratic society. And to the contrary, when officials are brought to cout for their actions or inactivities, it is perceived as a message that such behavior us not allowed, and the public begins to believe that no one is above the law.

In order to conclude, whether the principle of proportionality has been observed, it is necessary to ascertain either the means chosen by a legislator are suitable for achievement of legitimate aim and the action of a legislator is appropriate, or it is possible to use more careful means to achieve that aim,. If, after evaluation of a legal norm, it is acknowledged that this norm does not correspond to at least one of these criteria, it does not comply with the principle of proportionality and is illegitimate (Latvian Constitutional Court Verdict, 2010).

The bodies of operational activities, performing measures of operational actons, may limit rights of a person (see Section 116 of the Constitution of the Republic of Latvia).

For example, to evaluate the necessity of restriction stated in Section 7, Paragraph Five of the Operational Activities Law (In cases where immediate action is required in order to avert or detect terrorism, murder, gangsterism, riots, other serious or especially serious crime, as well as where the lives, health or property of persons are in real danger, the operational activities measures referred to in Paragraph four of this Section may be performed with the approval of a prosecutor. Approval of a judge must be obtained on the following working day, but not later than within 72 hours), it is necessary to verify whether the intervention of a body of operational activities into private life of a person is commensurate to the legitimate aim.

The principle of proportionality requires to observe a reasonable balance between public and individual interests in ther case, when the state power restricts rights and legitimate interests of a person (Latvian Constitutional Court Verdict, 2010). Thereby, it is necessary to evaluate, whether a balance is ensured, on the one hand, between rights of individuals on privacy and correspondence; and, on the other hand, between the operational aim of body of operational activities - to protect life and health, rights and freedoms, honor, dignity and property; to ensure the Constitution, the state system, national independence and territorial integrity, potentional of state defense, economical, scientific and technical potentials of the state, as well as to protect state secrets against external and internal threats; id est, to guarantee the public safety.

Without doubt, qualification and education of an employee of body of operational activities on the issues of human rights are of great importance.

The body of operatoral activities as an executive institution of the state power, which ensures observance and application of laws in relation to execution of human rights and fundamental freedoms, have to solve two 
problems. Firstly - bodies of operational activities have to respect and honour human rights and fundamental freedoms. Secondly - bodies of operational activities as law enforcement institutions, with their own practical actions, have to ensure the protection of human rights in mutual relations of natural persons, taking into account also public interests in the balanced correlation.

Due to the restrictions of privacy implemented by law, the State contributes to fight against criminality, allows a body of operational activities to respond immediately to the threats of expressly dangerous offences and to stop them, as well as to detect perpetrators.

The society must be confident that institutions of the state power are resolute to prevent violations of human rights.

\section{Conclusions}

The Operational Activities Law has been amended in due time. The legal provisions of the Operational Activities Law shall be clearly defined, because the measures of operational activities are prohibited for realization of other tasks and objectives.

The Operational Activities Law conforms with provisions of international human rights, however, additions are necessary.

Special investigative actions were carried out by the approval of an investigation judge, while measures of operational activities, similar in substance and implementation, - by approval of a judge of the Supreme Court.

It would be useful to expand a discussion about usefulness of introducng amendments in the Operational Activities Law, prescribing that measures of operational activities, performed in accordance with special method, are accepted by investigation judges.

It would be also preferable to evaluate usefulness of the amendments of Section 2, Paragraph Seven of the Operational Activities Law, because of the probability that it will be impossible to perform measures of operational activities in accordance with general method against mentioned persons.

It would be appropriate to evaluate usefulness of the amendments of Section 7, Paragraph Six of the Operational Activities Law, taking into account conditions of obtaining of the approval of a judge as well as time limits.

\section{References}

Allabouche, K.; Diouri, O.; Gaga, A.; El Amrani El Idrissi, N. 2016. Mobile phones' social impacts on sustainable human development: case studies, Morocco and Italy, Entrepreneurship and Sustainability Issues 4(1): 64-73. http://dx.doi.org/10.9770/jesi.2016.4.1(6)

Federalnyi zakon “Ob operativno-rozysknoi deyatelnosti” No. 144-F3 [The Federal Law on Operational Searching Activities]. 1995. Available in Internet: <http://base.consultant.ru/cons/cgi/online.cgi?req=doc;base=LAW;n=181943;fld=134;dst=1000000001,0;r $\mathrm{nd}=0.2762892712711391>$.

Gasparėnienė, L.; Remeikienè, R.; Sadeckas, A.; Ginevičius, R. 2016. Level and sectors of digital shadow economy: the case of Lithuania, Entrepreneurship and Sustainability Issues 4(2): 183-197. http://dx.doi.org/10.9770/jesi.2016.4.2(6)

Grozījumi Operatīvās darbības likumā [The amendments of the Operational Activities Law]. 2016. LV, 57 (5629), 22.03.2016./ Stājies spēkā 01.08.2016. Available in Internet: <http://likumi.lv/ta/id/281095-grozijumi-operativas-darbibas-likuma>.

Ivančiks, J. 2013. Piedāvāto grozījumu operatīvās darbības analīze [The analysis of the suggested amendments to the Investigatory Operations Law]. Administratīvā un Krimināla Justīcija, 3(64): 3-8.

Jälitustegevuse seadus [The Law on Video Surveillance]. 1994. Available in Internet: <http://www.riigiteataja.ee/akt/28648>. 
Lavrinenko, O; Ohotina, A.; Tumalavičius, V.; Pidlisna, O. 2016. Assessment of Partnership Development in Cross-Border Regions Innovation Systems (Latvia-Lithuania-Belarus). Journal of Security and Sustainability Issues, 6(1): 155-166. DOI: http://dx.doi. org/10.9770/jssi.2016.6.1(12).

Lietuvos Respublikos kriminalinėa žvalgybos įstatymas [The Law on Criminal Intelligence of the Republic of Lithuania]. 2012. Available in Internet: $<$ http://www3.lrs.lt/pls/inter3/dokpaieska.showdoc_1?p_id=437554>.

Operatīvas darbības likums [The Operational Activities Law]. 1993. Pieņemts Latvijas Republikas Saeimā, 16.12.1993, Stājies spēkā 13.01.1994.; ar grozījumiem, kas pieņemti lìdz ar 04.04.2012.

Pauceanu, A. M. 2016. Innovation and entrepreneurship in Sultanate of 0man - an empirical study, Entrepreneurship and Sustainability Issues 4(1): 83-99. http://dx.doi.org/10.9770/jesi.2016.4.1(8)

Štitilis, D.; Pakutinskas, P.; Malinauskaitè, I. 2016. Preconditions of sustainable ecosystem: cyber security policy and strategies, Entrepreneurship and Sustainability Issues 4(2): 174-182. http://dx.doi.org/10.9770/jesi.2016.4.2(5)

Teivāns-Treinovskis, J.; Amosova, J. 2016. Some aspects of criminal environment impact on sustainable entrepreneurship activities, Entrepreneurship and Sustainability Issues 4(1): 17-27. http://dx.doi.org/10.9770/jesi.2016.4.1(2)

Teivans-Treinovskis, J.; Lavrinenko, O. 2016. Assessment of Social Factors and Conditions Of Deviant Behavior In The Modern Society. Criminology Journal of Baikal National University of Economics and Law, 2016, Vol. 10, No. 1, pp. 73-81.

Tumalavičius, V.; Ivančiks, J.; Karpishchenko, O. 2016. Issues of Society Security: Public Safety under Globalisation Conditions in Lithuania. Journal of Security and Sustainability Issues, 5(4): 169-570. DOI: http://dx.doi.org/10.9770/jssi.2016.5.4(9).

Tvaronavičienè, A.; Žemaitaitienè, G.; Bilevičienè, T. 2016. Ecosystem for sustainable entrepreneurship: towards smart public procurement review procedures, Entrepreneurship and Sustainability Issues 4(1): 39-52. http://dx.doi.org/10.9770/jesi.2016.4.1(4)

Ustawa o czynnościach operacyjno-rozpoznawczych [The Law on Operational Intelligence Activities]. 2008. Available in Internet: $<$ http://orka.sejm.gov.pl/proc6.nsf/projekty/353_p.htm>.

Zahars, V.; Stivrenieks, M. 2016. Security and Safety Enforcment: Execution Peculiarities. Journal of Security and Sustainability Issues, 6(1): 72-77. DOI: http://dx.doi.org/10.9770/jssi.2016.6.1(12).

Zakon Ukrainy pro operativno-pozshukovu diyatelnost [The Law of Ukraine on Operational Searching Activities]. 1992. Available in Internet: <http://search.ligazakon.ua/1_doc2.nsf/link1/T213500.html>.

\section{About authors:}

Igors TROFIMOVS is Doctoral candidate in Law of Daugavpils University; Lecturer of the State Police College of Latvia. Research interests: Criminal Law; Criminal Intelligence; Issues of National, State and Regional Security.

Jānis IVANČIKS, PhD, is Professor of the Law Department of the Social Science Faculty at the Daugavpils University and of the Law Department of tne Law Faculty at the Turiba University. Research interests: Criminal Justice; Criminal Law; Criminal Intelligence; Security and Sustainability Issues. 